原

同種骨髄移植患者末梢血におけるサイトメガロウイルス DNA の

$\mathrm{PCR}$ による検出：CMV 抗体陰性血液輸血との関連

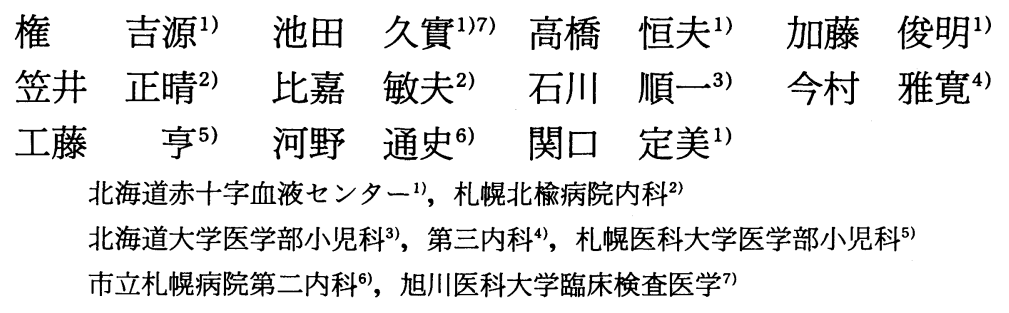

(平成 6 年 3 月 4 日受付)

\title{
DETECTION OF CYTOMEGALOVIRUS DNA IN PERIPHERAL BLOOD OF ALLOGENEIC BONE MARROW TRANSPLANT PATIENTS BY THE NESTED POLYMERASE CHAIN REACTION
}

\author{
Kil-Won Kwon' ${ }^{1)}$, Hisami Ikeda ${ }^{17)}$, Tsuneo A. Takahashi ${ }^{1)}$, Toshiaki Kato ${ }^{1)}$, Masaharu Kasai ${ }^{2}$, \\ Toshio Higa ${ }^{2)}$, Yorikazu Ishikawa ${ }^{3)}$, Masahiro Imamura $^{4)}$, Toru Kudoh ${ }^{5}$, \\ Michifumi Kono ${ }^{6)}$ and Sadayoshi Sekiguchi ${ }^{1)}$ \\ ${ }^{1)}$ Hokkaido Red Cross Blood Center \\ ${ }^{2}$ Department of Internal Medicine, Sapporo Hokuyu Hospital \\ ${ }^{3}$ Department of Pediatrics, Hokkaido University School of Medicine \\ ${ }^{4)}$ The Third Department of Internal Medicine, Hokkaido University School of Medicine \\ ${ }^{5}$ Department of Pediatrics, Sapporo Medical University School of Medicine \\ ${ }^{6}$ The Second Department of Internal Medicine, Sapporo City General Hospital \\ ${ }^{7)}$ Department of Laboratory Medicine, Asahikawa Medical College
}

In order to investigate the contribution of transfusion to CMV infection, $20 \mathrm{CMV}$ seropositive and 3 seronegative patients undergoing allogeneic bone marrow transplantation were studied for their CMV infection. All the patients received cellular blood component transfusion through a leukocyte depletion filter. CMV infection is defined as positive results with a nested double polymerase chain reaction (PCR) and/or IgM antibody testing. Blood samples of 10 healthy marrow donors and 10 pretransplant patients were available for PCR examination. No CMV-DNA was demonstrated. In contrast, among a total of 122 peripheral blood specimens from the 23 posttransplant patients, 51 from 14 patients were positive for CMV-DNA. Of 20 seropositive patients, 15 were transfused with CMV-seronegative blood which is consisted of $14.3 \%$ of blood donors and 5 were transfused with CMV-unscreened blood. Four $(80 \%)$ of the latter 5 seropositive patients showed CMV infection. Of 15 seropositive patients transfused with CMVseronegative blood, 11 (73.3\%) exhibited CMV infection. There was no significant difference in the incidence of CMV infection between the two seropositive patient groups (Fisher's exact probability test). In most cases, CMV infection occurred after 30 days post BMT. Interstitial pneumonia developed in two seropositive patients who had received CMV-seronegative blood products, and had positive results on both PCR and IgM testing. Regardless of transfusing 
CMV-unscreened or seronegative blood, none of the seronegative patients were infected with $\mathrm{CMV}$. Our present observations suggest that the CMV-seronegative blood component contributes little if any to prevent seropositive patients from CMV infection.

\section{緒言}

骨髄移植（BMT）後のサイトメガロウイルス (CMV) 感染症を予防する手段のひとつとして輸 血血液を $\mathrm{CMV}$ 抗体陰性製剂に限定することがあ げられる.特に患者が CMV 抗体陰性の場合には, CMV 抗体陰性血流製剤の絶対的適応とされてい る ${ }^{1) ~ 3)}$. 一方, CMV 抗体が移植前に陽性の患者に 対しては陰性血液使用の適応があるか否かについ ては明確な見解が存在しない. 欧米では陰性血液 輸血の必要性が特に考慮されていないが，本邦で は抗体陽性者に対しても抗体陰性血液製剤が CMV 感染症予防に同じく有効とする報告 ${ }^{4}$ が見 られる。

CMV 浸淫の高い本邦においては, 骨髄移植を 行っている医療機関からの抗体陰性血液供給の要 請に対し, 血液センター側で充分量の陰性血液を 用意することに困難を伴う場合がある。またその 抗体陰性血液の適応に関しても上述のように相反 する対応がなされている状況である，そこで本研 究では既に CMV 抗体が陽性の患者への抗体陰性 血液輸血が, 同種骨髄移植後の CMV 感染顕在化. 再感染防止にどのように影響し，効果を有するか 検討する目的で, 移植後の患者検体から CMVDNA 検出を行ったので報告する.

\section{対象と方法}

\section{1. 被験患者}

被験者は北海道赤十字血液センターで調製され たシングルドナーアフェレーシス由来血小板製剤 を使用した同種骨髄移植患者である．医療機関よ り要請のあった患者に対しては，アフェレーシス 血小板製剂，濃厚赤血球製剤ともに CMV 抗体陰 性のものが供給された. その中で, BMT 後に末梢 血検体を採取し得た CMV 抗体陰性血液輸血患者 17例，未スクリーニング血液輸血患者 6 例の計 23 例を対象とした。その内訳を Table 1 に示した。 両群の患者における当センター調製アフェレーシ ス血小板製剤の平均輸血回数は, 本検討期間内で
Table 1. Patient characteristics

\begin{tabular}{ccc}
\hline & \multicolumn{2}{c}{ Transfused blood } \\
\cline { 2 - 3 } & CMV-seronegative & Unscreened \\
\hline Total patients & 17 & 6 \\
Sex (male : female) & $14: 3$ & $4: 2$ \\
Median age (y) (range) & $17(3-38)$ & $25.5(9-35)$ \\
Underlying disease & & \\
ALL & 7 & 2 \\
ANL & 3 & 2 \\
CML & 3 & 1 \\
AA & 3 & 0 \\
Lymphoma & 1 & 1 \\
\hline
\end{tabular}

前者が15.3回，後者が15.9回であった。なお，白 血球除去赤血球製剂以外の血球製剂は全てベッド サイドで白血球除去フィルター（旭メディカル社 製セパセル R-500，セパセル PL-10，Pall 社製 PL100）を通して患者に輸血された。また，患者は 全例とも CMV 感染症予防のため CMV 抗体高力 価の $\gamma$-グロブリン製剤の投与を受けていた。

\section{2. $\mathrm{CMV}$ 抗体の測定}

献血者血液からの抗体陰性輸血用血液は $\mathrm{CMV}$ 抗原感作ゼラチン粒子を用いた凝集法 $(\mathrm{PA})^{5)}$

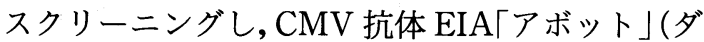
イナボット）で陰性であることを確認した。骨髄 移植患者検体についてはエンザイグノスト一サイ トメガロ EIA（ヘキストジャパン）により IgG, IgM 抗体を分別測定した。

3. CMV-DNA の検出

既報6)のように CMV ゲノムの前初期抗原コー ド領域 exon 4 を標的とした二重ポリメラーゼ連 鎖反応増幅法 (PCR) を実施し，420塩基対（bp） の増幅産物の有無をアガロース電気泳動，エチジ ウムブロマイド染色により検討した。この増幅産 物は内部に制限酵素 Bg1 II の反応部位を有して おり (Fig. 1A)，酵素消化により 150bp と270bp の 二つの断片を生ずることで増幅産物の特異性を確 認した。

\section{CMV 感染の定義}


A

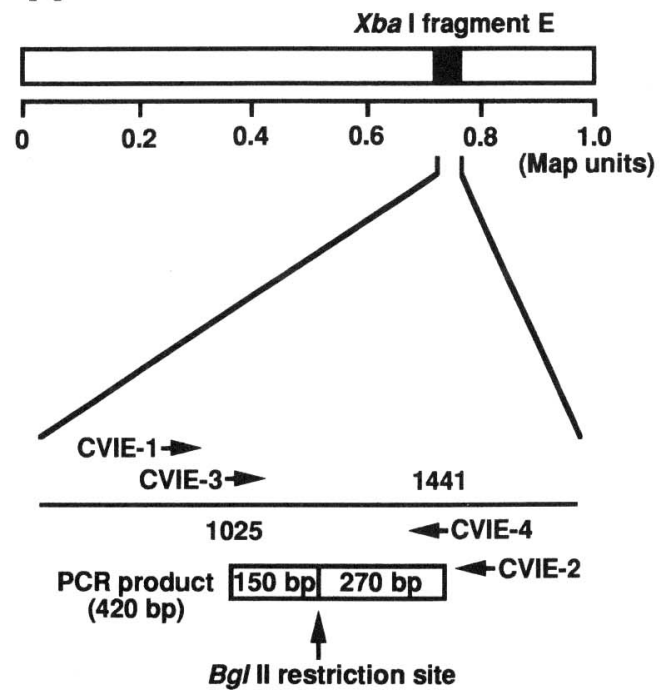

B

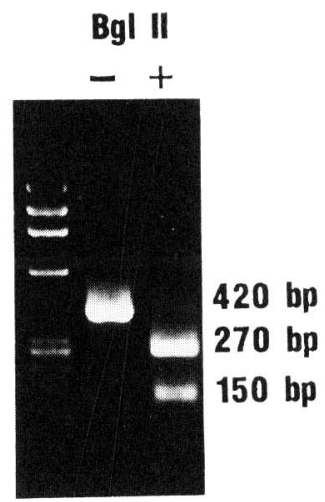

Fig. 1 (A) Amplification of the CMV-IE region by the nested double PCR. (B)

Specific PCR product confirmed by restriction enzyme (Bg1 II) digestion.

骨髄移植患者より得られた検体で, 上述の PCR および IgM 抗体 EIA の一方または両方が陽性と なった場合, これを本検討では「CMV 感染」と定 義した.この定義は別報67)の如く今回用いた PCR の系では健康人において CMV-DNA の有意な増 幅がみられないこと, また特異的 IgM 抗体はウイ ルスの初感染, 再活性化時の重要な血清学的マー カーであることに基づく.

5 . 有意差検定

Fisher の直接確率計算法により $\mathrm{p}<0.05$ の場合 を有意とした.

\section{結 果}

1. BMT 関連末梢血検体からのCMV-DNA 検出

移植後の患者では23例の計122検体中, 14例51検 体が PCR 陽性となった。これらの検体の増幅産 物は制限酵素 Bg1 II 消化により $270 \mathrm{bp}$ と $150 \mathrm{bp}$ のバンドを生ずることから，CMVゲノムに由来 する特異的増幅産物であることが確認された。そ の代表例を Fig. 1B に示した. 一方, 対照群とし て PCRによる検討が可能であった健康な骨髄ド ナー10例 (内 CMV 抗体陽性者 7 例) および BMT 施行前の患者10例（同 9 例）の末梢血検体では
CMV-DNA は全例検出されなかった.

2. BMT 後の患者における輸血血液別 $\mathrm{CMV}$ 感染頻度

BMT 患者を CMV-Ab (一) 血液輸血群と末ス クリーニング血液輸血群とに分け，末梢血液での PCR の結果を Fig. 2, Fig. 3 に時系列で示した. CMV-IgM 抗体は, 前者群において PCR が陽性 であった 2 例（\#34，\#37）と PCR 陰性の\#50の計 3 例で検出され, 後者群では PCR 陽性の 1 例（\# 36）で検出された.

CMV 感染が認められた患者数を BMT 患者, 骨髄ドナーおょび輸血血液の CMV 抗体の有無で 分類して Table 2に示した. 移植前に CMV 抗体 陰性であった患者 3 例（\#27，\#30，\#39）に扔いて は,末スクリーニング血液が輸血された 1 例(\#39) も含めて PCR は陰性であった。一方, 移植前に CMV 抗体陽性の患者では骨髄ドナーも CMV 抗 体陽性の場合, 輸血血液の違いによる感染頻度 (8/11 vs $4 / 4)$ に差は認められなかった（p= 0.36)。骨髄ドナーが CMV 抗体陰性の場合は例数 が少ないため比較できないが，抗体陰性血液の輸 血を受けた患者 4 例中 3 例に CMV 感染がみられ た. 輸血血液の要因のみを考慮して検討すると 


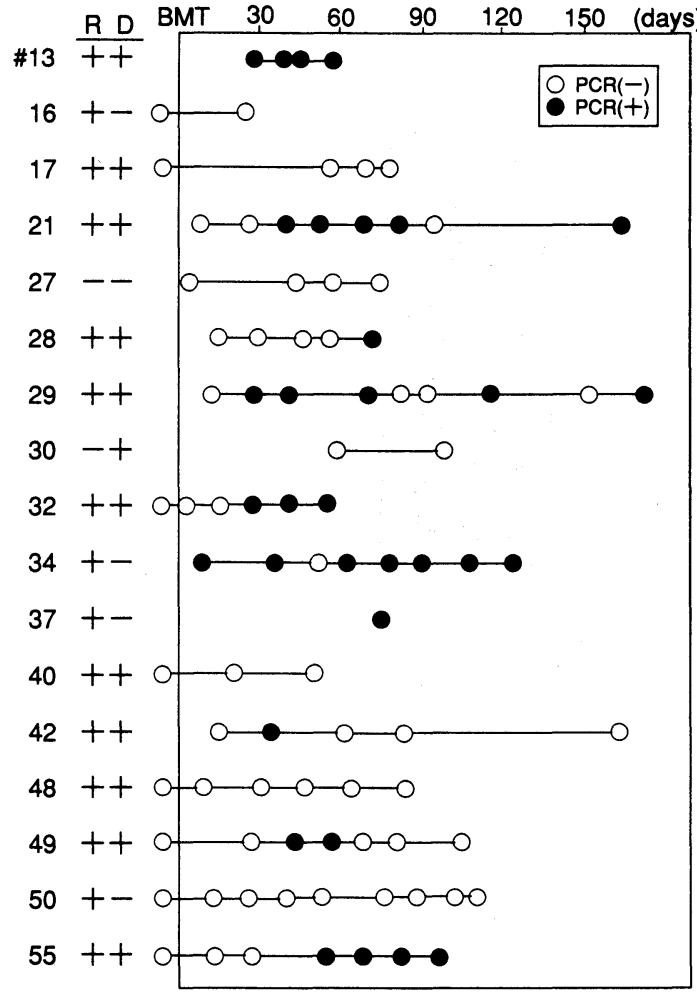

Fig. 2 Detection of CMV-DNA in BMT patients receiving $\mathrm{CMV}$-seronegative blood products. + or - indicates CMV serostatus in BMT recipient (R) and donor (D).

Table 3 に示したように，抗体陽性の患者におい ては輸血血液の CMV 抗体の有無に関わらず $\mathrm{CMV}$ 感染頻度に有意差を認めなかった（p= $0.63)$.

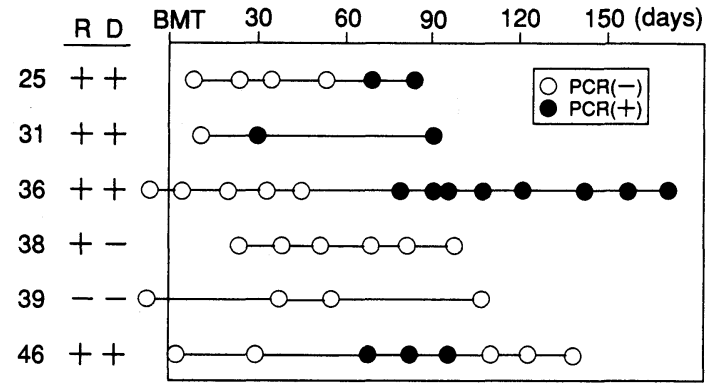

Fig. 3 Detection of CMV-DNA in BMT patients receiving $\mathrm{CMV}$-unscreened blood products. + or - indicates CMV serostatus in BMT recipient (R) and donor (D).

CMV 感染症は, 追跡期間中にCMV-DNA, $\operatorname{IgM}$ 抗体ともに陽性となった\#34の患者で移植後 約60日目以降に,また\#37の患者で移植後29日目に 間質性肺炎の発症がみられた。

3. IgM 抗体の消長

経時的に複数の血清検体について検討しえた患 者\#34, \#36, \#50における CMV-IgM 抗体の消長を Fig. 4 に示した. 移植直後より PCR が陽性で あった\#34の患者では, IgM 抗体はそれより遅れ て約50日から80日目にかけて検出され，この IgM 抗体出現中に間質性肺炎の発症がみられた.\#36の 患者においても IgMの出現よりCMV-DNAの 検出が先行した.しかし\#50の患者では IgM 抗体 の出現の有無に関わらず，本検討で用いた PCR では CMV-DNA は検出されなかった。

Table 2 Incidence of $\mathrm{CMV}$ infection in allogeneic bone marrow transplant patients

\begin{tabular}{|c|c|c|c|c|c|c|c|}
\hline \multirow{2}{*}{\multicolumn{2}{|c|}{ CMV serostatus }} & \multirow{4}{*}{$\begin{array}{l}\begin{array}{l}\text { Transfused } \\
\text { blood }\end{array} \\
\text { CMV-Ab (-) } \\
\text { Unscreened }\end{array}$} & \multirow{3}{*}{ No. of patients } & \multicolumn{4}{|c|}{ CMV infection } \\
\hline & & & & \multirow{2}{*}{$\frac{\text { Total }}{8}$} & \multirow{2}{*}{$\frac{\mathrm{PCR}(+) / \operatorname{IgM}(+)}{0}$} & \multirow{2}{*}{$\frac{\operatorname{PCR}(+) / \operatorname{IgM}(-)}{8}$} & \multirow{2}{*}{$\frac{\mathrm{PCR}(-) / \operatorname{IgM}(+)}{0}$} \\
\hline $\mathrm{R}+$ & $\mathrm{D}+$ & & & & & & \\
\hline & & & 4 & 4 & 1 & 3 & 0 \\
\hline \multirow[t]{2}{*}{$\mathrm{R}+$} & $\mathrm{D}-$ & $\mathrm{CMV}-\mathrm{Ab}(-)$ & 4 & 3 & 2 & 0 & 1 \\
\hline & & Unscreened & 1 & 0 & & & \\
\hline \multirow[t]{2}{*}{$\mathrm{R}-$} & $\mathrm{D}+$ & $\mathrm{CMV}-\mathrm{Ab}(-)$ & 1 & 0 & & & \\
\hline & & Unscreened & Nil & & & & \\
\hline \multirow[t]{2}{*}{$\mathrm{R}-$} & $\mathrm{D}-$ & $\mathrm{CMV}-\mathrm{Ab}(-)$ & 1 & 0 & & & \\
\hline & & Unscreened & 1 & 0 & & & \\
\hline
\end{tabular}

$\mathrm{R}$ (recipient) : $\mathrm{D}$ (donor) 
Table 3 Incidence of CMV infection in CMV seropositive patients having received allogeneic bone marrow transplantation

\begin{tabular}{l|c|c}
\hline Transfused blood & No. of patients & CMV infection ${ }^{1)}(\%)$ \\
\hline CMV-Ab (-) & 15 & $11(73.3)^{*}$ \\
Unscreened & 5 & $4(80.0)^{*}$ \\
\hline
\end{tabular}

1) $\mathrm{CMV}$ infection is defined as positive results with PCR and/or IgM antibody testing.

* Not significant (Fisher's exact probability test).
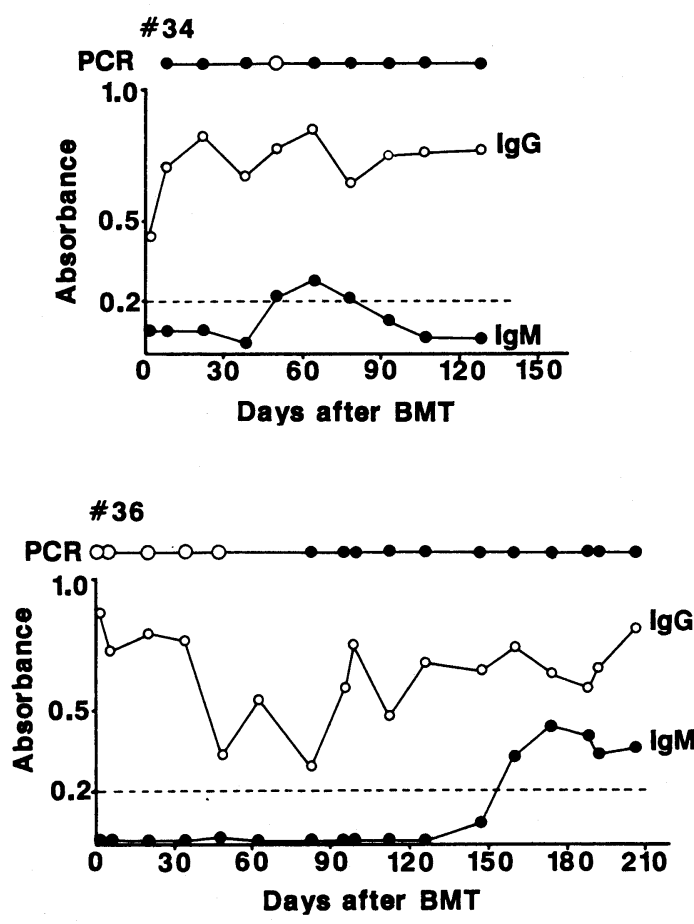

Fig. 4A CMV antibody status of BMT patients (\# $34, \# 36)$. The dashed line on absorbance 0.2 represents cut-off level of IgM antibody testing. Circles in the upper straight line show PCR result $(O$ : negative, : positive).

\section{考 察}

今回の検討は，同種骨髄移植前に CMV 抗体陽 性である患者において, CMV 感染の発生頻度が 移植後に使用した輸血血液の CMV 抗体の有無に よりどのような影響を受けるかを明らかにするた めに行われた．現実的には，ほとんどの骨髄移植 実施病院で移植患者へ用いる血液は全てべッドサ イドで白血球除去フィルターを通して輸血されて

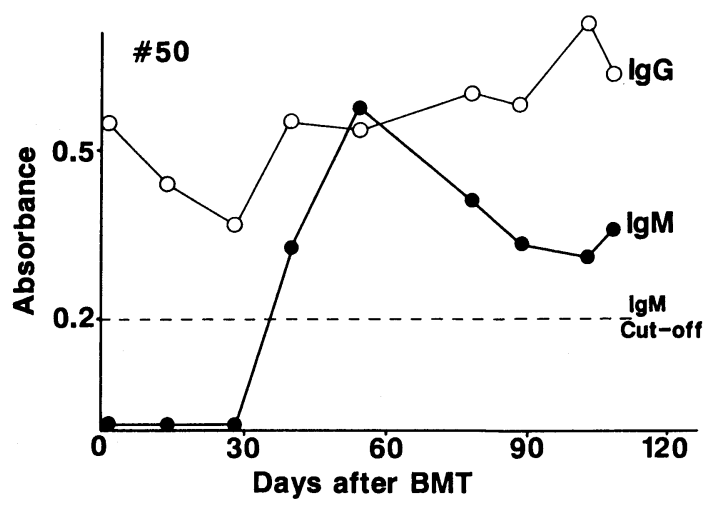

Fig. 4B CMV antibody status of BMT patient (\# $50)$.

いるため, 本研究もその条件下での比較検討と なった。

健康人の末梢血における CMV-DNA の存在頻 度は，本検討で用いた二重 PCR の検出限界であ る白血球 $10^{5}$ 個に 1 コピー以下であることを既に 報告した ${ }^{6) 7}$. 実際, CMV 抗体陽性者 7 例および 9 例をそれぞれ含む骨䯣ドナー10例，BMT 施行前 の患者10例はいずれも PCR 陰性であった。従っ て今回用いた PCRによる陽性の判定結果は, CMV 抗体陽性健常人において免疫系による監 視, 排除を免れている CMV-DNA の存在頻度, 存 在様式を逸脱していることを意味していると考え られる.CMV-DNA 検出や IgM 抗体検出によっ て認められる CMV 感染の顕在化が直ちに間質性 肺炎のような CMV 感染症につながるわけではな いが, 発症にはウイルスの増殖, 顕在化が前提と なる。

北海道センターでの献血者の CMV 抗体陽性率 は85.7\% (7022/8193) であり，末スクリーニング 血液輸血患者群に使用されたアフェレーシス血小 板を含む血液製剤の大半は $\mathrm{CMV}$ 抗体陽性者由来 とみなせる。移植前に CMV 抗体が陽性であった 患者においては，この未スクリーニング血液製剤 を輸血された群と抗体陰性製剂輸血群とで CMV 感染頻度に有意差を認めなかった (Table 3). そ の理由としては，同種骨髄移植において患者自身 $\mathrm{CMV}$ 抗体陽性であることが CMV 感染重篤化の 最大のリスクファクターであり，この場合の輸血 
血液は二次的な影響しかもたらしえない(12) とい うこと，また，ベッドサイドでの白血球除去フィ ルター使用により末スクリーニング血液と CMV 抗体陰性血液が CMV 感染防止効果において等価 となった可能性などが考えられる.

時系列の検討では両群の患者とも移植後およそ 30 日以降に PCR 陽性となる例が多く見られた (Fig. 2, Fig. 3)。これは CMV 感染症, 特に肺炎 が好発する時期9)と重なりあっており，PCR 検査 所見の臨床的意義を示唆するものとして興味深 い.

EIA により IgM 抗体が検出された症例のうち \#50は末梢血検体すべてで PCR 陰性となった。 PCR の標的とした部位は CMV 臨床株間でも良 好に保存 ${ }^{11}$ されている前初期抗原コード領域 exon 4であるが，\#50の患者に IgM 産生を惹起し た CMV 株はこの領域に変異を起こしているため に検出できなかった可能性が考えられる.またこ のことは, PCR のみで CMV 感染を検討しょうと する場合には異なった 2 つ以上の領域を標的とす

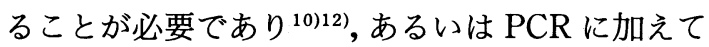
$\operatorname{IgM}$ 検査などを併用することが不可欠であるこ とを示している。なお今回 IgG 抗体も測定した が，抗 CMV 抗体高力価の $\gamma$-グロブリン製剤投与 により EIA の吸光度が変動し影響を受けたため (Fig. 4 参照)，その上昇をもって患者における $\mathrm{CMV}$ 感染と判断する基準は採用しなかった.

PCR, IgM 抗体ともに陽性となった\#34と\#36の 2 例ではいずれも IgM 抗体の出現に先駆けて PCR で CMV-DNA が検出された (Fig. 4).この 結果は，患者における迅速な CMV 感染モニタリ ングとして PCR が有用であるとするこれまでの

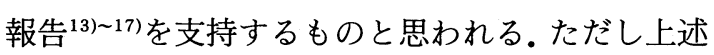
のようにウイルス遺伝子の 1 領域のみを標的とし た場合には検出不能となる例があること，2 力所 以上を標的とした場合でも領域によって PCR の 検査結果, 陽性頻度に違いがみられるという報 告 ${ }^{812)}$ があることを考慮する必要があろう.

一部の患者では末梢血検体と併せて尿検体を PCR で検討したが, 多くの場合尿検体において PCR 陰性となった(結果は表示せず)。この理由と
して, 尿中には PCR 阻害物質が存在すること ${ }^{10)}$, 新鮮尿ではなく凍結保存尿で検討したため阻害物 質の影響が大きくなったこと等が考えられる．本 PCR の尿検体への適用には, 阻害物質除去等の前 処理を検討することが必要と思われる.

移植前に既に CMV 抗体が陽性の患者の場合, 移植後の CMV 感染症発症は主として患者に潜伏 感染していたウイルスの再活性化によると考えら れている ${ }^{1819)}$. 本研究においても, 骨髄ドナーおよ び輸血血液の CMV 抗体がともに陰性であった 4 例の抗体陽性患者のうち 3 例にウイルス顕在化が 認められたことから, 既感染患者での移植後の CMV 感染は患者自身の CMV 再活性化に起因す る可能性が高いと思われる。輸血を通じての異 なった CMV 株による再感染が CMV 感染症発症 の危険性に大きく関与しているという分子生物学 的根拠は，これまでのところ示されていない。ま た今回の検討でみられた, 移植直後の検体で CMV-DNA が検出され間質性肺炎を発症した\#34 の患者のような例では, CMV 抗体陰性血液を輸 血し続けることに臨床的意義を見いだすのは難し い.

\section{結 論}

ベッドサイド白血球除去フィルター使用のもと で行われた今回の検討では, CMV 抗体陽性患者 への同種骨髄移植後の輸血において CMV 抗体陰 性血液と末スクリーニング血液の CMV 感染予防 効果に差を認めなかった。抗体陰性血液製剤の使 用については血液センター側と医療機関の間で十 分なコンセンサスを形成することが必要と思われ る.

\section{文献}

1) Preiksaitis, J.K.: Indications for the use of cytomegalovirus-seronegative blood products. Transfus. Med. Rev., 5 : 1-17, 1991.

2) Hillyer, C.D., Snydman, D.R. and Berkmann,J E.M. : The risk of cytomegalovirus infection in solid organ and bone marrow transplant recipient: Transfusion of blood products. Transfusion, $30: 659-666,1990$.

3) Sayers, M.H., Anderson, K.C., Goodnough, L. T., Kurts, S.R., Lane, T.A., Pisciotto, P. and Silberstein, L.E.: Reducing the risk for 
transfusion-transmitted cytomegalovirus infection. Ann. Intern. Med., 116: 55-62, 1992.

4）矢部みはる, 矢部普正, 満田るみ, 小松田光真, 加藤俊一, 田中重明: 同種骨髄移植後のサイトメ ガロウイルス感染症発症の要因と予防. 移植, 24 : 493-497, 1989.

5）大矢健一，都築陽子，船戸悦二，鈴木具子，倉知 透, 村瀬隆治, 水野伸一, 山口 博, 長谷川岩三, 森島泰雄, 神谷 忠, 小久保幸雄 : ゼラチン粒子 を用いたサイトメガロウイルス抗体測定法の碓 立. 日輸血会誌, $37: 44-47,1991$.

6）漆原範子, 権 吉源, 高橋恒夫, 関口定美 : PCR による末梢血からの CMV-DNA 検出の試み。日 輸血会誌, 39: 544-549, 1993.

7) Urushibara, N., Kwon, K.W., Takahashi, T.A. and Sekiguchi, S.: Human cytomegalovirus DNA is not detectable with nested double PCR in healthy blood donors. Vox Sang., in press.

8）大熊重則, 宮原正行, 佐藤博正, 宮本寛治, 福田 俊一, 永井 宏, 瀬崎達雄: CMV-DNA 検出法の 検討一骨髄移植等患者群と健常人の比較.日輸血 会誌, $40: 296,1994$.

9）加藤俊一：骨髄移植とサイトメガロウイルス肺 炎. 日本臨床, 47: 446-451, 1989.

10) Demmler, G.J., Buffone, G.J., Schimbor, C.M. and May, R.A.: Detection of cytomegalovirus in urine from newborns by using polymerase chain reaction DNA amplification. J. Infect. Dis., 158: 1177-1184, 1988.

11) Shibata, M., Morishima, T., Terashima, M., Kimura, H., Kuzushima, K., Hanada, N., Nishikawa, K. and Watanabe, K. : Human cytomegalovirus infection during childhood: Detection of viral DNA in peripheral blood by means of polymerase chain reaction. Med. Microbiol. Immunol., 179 : 245-253, 1990.

12) Shibata, D., Martin, W.J., Applemann, M.D., Causey, D.M., Leedmann, J.M. and Arnheim, N.: Detection of cytomegalovirus DNA in peripheral blood of patients infected with human immunodeficiency virus. J. Infect. Dis., 158: 1185-1192, 1988.

13) Jiwa, N.M., Van Gemert, G.W., Raap, A.K., Van de Rijke, F.M., Mulder, A., Lens, P.F.,
Salimans, M.M.M., Zwaan, F.E., Van Dorp, W. and Van der Ploeg, M.: Rapid detection of human cytomegalovirus DNA in peripheral blood leukocytes of viremic transplant recipients by the polymerase chain reaction. Transplantation, 48: 72-76, 1989.

14) Cassol, S.A., Poon, M.-C., Pal, R., Naylor, M.J., Culver-James, J., Bowen, T.J., Russell, J.A., Krawetz, S.A., Pon, R.T. and Hoar, D.I.: Primer-mediated enzymatic amplification of cytomegalovirus (CMV) DNA : Application to the early diagnosis of CMV infection in marrow transplant recipients. J. Clin. Invest., 83 : 1109-1115, 1989.

15) Rowley, A.H., Wolinsky, S.M., Sambol, S.P., Barkholt, L., Ehrnst, A. and Andersson, J.P.: Rapid detection of cytomegalovirus DNA and RNA in blood of renal transplant patients by in vitro enzymatic amplification. Transplantation, 51: 1028-1033, 1991.

16) Einsele, H., Steidle, M., Vallbracht, A., Saal, J. G., Ehninger, G. and Mueller, C.A.: Early occurrence of human cytomegalovirus infection after bone marrow transplantation as demonstrated by the polymerase chain reaction technique. Blood, 77 : 1104-1110, 1991.

17) Zipeto, D., Revello, M.G., Silini, E., Parea, M., Percivalle, E., Zavattoni, M., Milanesi, G. and Gerne, G. : Development and clinical significance of a diagnostic assay based on the polymerase chain reaction for detection of human cytomegalovirus DNA in blood samples from immunocompromised patients. J. Clin. Microbiol., 30 : 527-530, 1992.

18) Winston, D.J., Huang, E.-S., Miller, M.J., Lin, C.-H., Ho, W.G., Gale, R.P. and Champlin, R.E. : Molecular epidemiology of cytomegalovirus infections associated with bone marrow transplantation. Ann. Intern. Med., $102: 16-20,1985$.

19) Kanesaki, T., Baba, K., Tanaka, K., Ishibashi, M. and Yabuuchi, H.: Characterization of cytomegalovirus isolates recovered during repeated infection in renal transplant recipients. J. Med. Virol., 28 : 140-143, 1989. 